\title{
Turkish Politics: Between Europe and Islam
}

\author{
Kyle Wallace
}

\begin{abstract}
Since the inception of Turkey as an independent state, the country has based itself on Western modes of governance, with secularism being a hallmark of the nation. In recent years, Islamic parties have made inroads in government, causing consternation among the old guard and allies in Europe. Much of the modern arguments against Turkey's inclusion in the EU rely on psuedo-Orientalist ideas; Turkey is somehow so different and alien from "European" culture that they simply do not belong in the EU. Historical notions of Turkey and Islam as fundamentally different are then propagated to remove Turkey from contemporary Europe. Islamic politics in Turkey do not represent a shift to a more fundamentalist ideology; in actuality, Turkish Islamic parties are very modern movements based in progressive ideas. The rise of Islamic parties in Turkey signals a shift away from a dogmatic following of the strictly secular West into a more hybrid political identity, unshakably tied to the West but allowing for a greater expression of its Middle Eastern Muslim heritage.
\end{abstract}

Turkey has long fought for acceptance by the European Union, and. in the late 1990s, it looked as though this was closer than ever with the Helsinki Accord in 1999 setting the basis for Turkish membership in the European Union. Following the accord, the EU and Turkey proceeded with ascension talks in 2004, although little progress has occurred since. In Europe, there has been a rise in those opposed to Turkish membership; in the past, these groups focused on the poor human rights record and un-democratic actions of Turkish governments, but now the debate has turned to the less concrete notion of culture. Europeans increasingly question the character of Turkey and whether it belongs in the EU based on Turkey's so-called "alien" culture. Culture represents a possibly insurmountable barrier to Turkish entry into the EU, and has resulted in a flurry of literature on why Turkey should be excluded or included in the European community. Those who would reject Turkey on cultural grounds see Turkey as simply foreign to the European culture, despite the incongruities on what European culture actually is.

The cultural critiques of Turkey follow a line of thinking that Europe has long employed towards Islam and the Middle East--that of Orientalism. The discourse of Turkey possessing a culture supposedly incompatible with Europe is merely the continuation of the long historical process of 'othering.' In this case, it is the other of Islam and Turkey, creating a dichotomy between 'us' and 'them.' Those opposed to Turkish inclusion in the EU approach the topic as a 'clash of civilizations,' where the 'degenerated' Islamic-influenced culture of Turkey will somehow bring about the end of European culture. ${ }^{1}$ Turkey is then portrayed as part of a substandard culture, and historical arguments are applied to situate the Turks as an outsider to European civilization. Turkey's application for EU membership is indeed a continuous and ongoing issue, but the agreements made to exclude it from EU ascension are firmly rooted in historical 'facts.'

The Islamic nature of Turkey is then cited as the major cultural difference, as the Islamic religion supposedly is incompatible with modern secular European beliefs. Turkey has indeed experienced

${ }^{1}$ Edward Said, “Orientalism 25 Years Later: Worldly Humanism vs. The Empire Builders,” accessed April 8, 2011, http://www.counterpunch.org/said08052003.html.

Constellations

Volume 2, No. 2 (Winter 2011) 
an increase in the presence of Islam in its politics, although this differs immensely from other "traditionalist" Islamic politics; these are Islamic parties similar in outlook to Christian Democratic groups in Germany--not radical groups like those in Iran. Political Islam emerged in Turkey over the last few decades. However, this Islamism is based upon long established Western values in Turkey, particularly secular governance. Turkey sits at a crossroads of identity where it is being slowly turned away from the world it was so desperately trying to gain entry to. Turkey now seems ready to forge ahead on its own unique path, constructing a new character that does not orient itself specifically to the West or the East.

In recent years, there has been a glut of literature produced focusing on the future of the EU and Turkey. The original arguments rejecting Turkey's EU membership focused primarily on economic and political issues, but Turkey has made great strides in these sectors in recent years. Asa Lundgren questions the enlargement policies of the EU and finds that Turkey is, at least on paper, a more suitable candidate for EU membership than existing members such as Romania. Lundgren makes the case that the Eastern European countries were simply viewed as a higher priority than Turkey, receiving far greater economic and moral support. ${ }^{2}$ The same support is lacking for Turkey, despite the 1963 Ankara agreement which saw European delegates officially declare Turkey as a "European state" which shared the cultural values and institutions of Europe. ${ }^{3}$ Turkey has been officially trying to get into the EU for over thirty years, while Eastern Europe applied and was accepted in less than twenty. Turkey and Romania scored close on political rights and openness, while Turkey scored far higher in all major economic categories. ${ }^{4}$ Lundgren does convey that Turkey has problematic politics, but no issue is far from what Romania or many other Eastern European countries have faced.

In Turkey's case, economic and political issues are amplified, whereas the Eastern European states were able to essentially enter into negotiations to join the EU without strenuous examinations of these problems. Even with the Helsinki Accord that allowed Turkey to finally be considered for full membership, there have been no expedited attempts to get their entrance into the EU, as opposed to the Eastern European states that were rushed along to full membership. To many in the EU, Turkey has become a partner but not an equal. Turkey is a bridge between Asia and Europe that will be beneficial to the EU--but not as a full member. ${ }^{5}$ As Eastern Europe continues to have economic and social problems similar to Turkey, while still being allowed full membership, their quick ascension can be attributed to some quality they possessed that Turkey lacked. Perhaps the EU perceived Eastern Europe as naturally belonging while Turkey was seemingly deficient of a 'European' identity.

Turkish reaction to the EU and its ambivalence towards Turkish membership began to create doubts in Turkey. Pulat Tacar argues that Turks in general are uninformed of what exactly membership to the EU will entail for the people of Turkey. The majority of Turks in polls often proclaim they want EU membership but are unaware of the concessions they will have to allow in order to attain ascension. Turkey will need to spend forty billion euros on environmental infrastructure, settle the long running Cyprus dispute, and re-educate and transfer up to ten million

\footnotetext{
${ }^{2}$ Asa Lundgren, “The Case of Turkey: Are Some Candidates More 'European' than Others?” in Questioning EU

Enlargement: Europe in Search of Identity, ed. Helen Sjursen. (London \& New York: Routledge, 2006,) 125

${ }^{3}$ Ibid., 137

${ }^{4}$ Ibid., 129

${ }^{5}$ Ibid., 136.
} 
people out of the agricultural sector to comply with EU standards. ${ }^{6}$ Little of this information is public knowledge as thousands of pages of EU legislature and official documents remain untranslated into Turkish, and even then it is unlikely politicians pushing for membership would publically proclaim such problems. ${ }^{7}$

Despite all these problems, Turkey still pushes for membership with public support. Despite the public's lack of knowledge about the forty billion euro process, the fact that the public vigorously supports ascension gives the appearance of an elite-driven political movement. The ascension of Turkey presents legitimate issues that will most likely result in society-wide changes for Turkey as a nation. The larger public debate favours discussions of whether Turkey can culturally exist in the EU instead of the more grievous issues, revealing the knowledge gap between the people and the elites driving the movement. No group pushing through change will focus on the negative aspects. By framing the argument of Turkish ascension as one of cultural discrimination by Europeans, Turkish authorities are attempting to nationalize the EU membership process. Turkish officials appeal to nationalism, and, as a result, anything less than full membership with the EU results in a slap to the face of the Turkish nation. ${ }^{8}$

Appealing to Turkish nationalism is also used by the Euro-sceptics in Turkey, who wish to paint the EU as another colonial project with the end goal of dismantling the Turkish state. Menno Spiering also portrays EU membership as a top-down and elite driven process. New data shows that past polls on EU support were often exaggerated, with the significant rural population of Turkey much more wary of the EU. ${ }^{9}$ This top down method is not a uniquely Turkish phenomenon as much of the EU developments in Europe have also been driven by elites. ${ }^{10}$ The top-down nature on both sides is then able to use national and cultural identity to appeal to a broader mass of people, allowing for the creation of new identities previously not existing. In the case of the EU, the 'othering' of the Turk provides a convenient way to establish a unified European identity among vast swathes of ethnic and cultural boundaries. From the Turkish perspective, many see the EU as an affront to their own carefully constructed national identity. Ironically, for many Turks preferring a more limited associative status with the EU, the issue of membership has become an integral point of pride. ${ }^{11}$ Since the early days of the Turkish republic, there has been a state-driven, Western-based reform process aimed at creating a European-styled society. As membership to the EU would be the culmination of this national goal, it is not hard to imagine the trauma that rejection would pose for the national psyche.

As membership in Turkey comes under attack from Europeans, Turkey has pushed back. The 'othering' of Turkey by Europeans is not a one-way street. Many Turks have asserted that Europe is in actuality very different; it is a closed Christian club that only puts on the face of inclusion and multiculturalism, but which will not follow through on its so called inclusive beliefs. ${ }^{12}$ Among right wing Islamists in Turkey, the EU is seen as a Christian-Zionist alliance with the end goal being the

${ }^{6}$ Pulat Tacar "Socio-cultural Dimensions of Accession Negotiations," in Turkey and the European Union: Prospects for a Difficult Encounter, eds. Esra Lagro and Knud Erik Jorgensen. (New York: Palgrave Macmillan, 2007,) 132, $133,134$.

7 Ibid., 140.

8 Tacar, 130.

${ }^{9}$ Menno Spiering, "Euro-sceptic Concerns about National Identity in the European Union and Turkey," in Turkey and the European Union: Prospects for a Difficult Encounter, eds. Esra Lagro and Knud Erik Jorgensen. (New York: Palgrave Macmillan, 2007), 175.

10 Ibid., 181.

11 Ibid., 176.

12 Spiering, 177. 
control and dismemberment of the Turkish nation and Islamic culture. ${ }^{13}$ As Turkey and Europe begin to foster views of each other as distinctly foreign, it pushes a wedge between the two that is encased in a similar language. Turkey wishes to act as a part of the EU, but the latter's seeming disinterest forces Turkey away from the West. Pushing Turkey away causes problems for Turkish national identity as it is strongly based on Western ideas and beliefs, which alienation by Europe only antagonizes. The promised integration into the EU has encouraged Turkey to undergo reforms which have made society much more open and democratic and, ironically, has aided in the rise of Islamic parties that the West is so wary of.

If Turkey is rejected by the EU for membership it will most likely turn away from the West, but that does not mean it will descend into a radical Islamic state. Omer Caha opens his article with multiple references stressing Turkish-European identity. He reaches back to the times of the Ottomans, using their role as the "sick man of Europe" as an indicator of European identity, and mentions the 1856 Treaty of Paris which established Ottoman identity as European. ${ }^{14}$ He rightly explains the secular aspect of Turkish culture as firmly rooted in Western values, along with the French-based Turkish constitution and Swiss-inspired legal code. ${ }^{15}$ Caha views Turkey as a hybrid culture, one which takes predominantly from the West, but does not deny its Muslim heritage or identity. The stress on the modern character of Turkey is clearly an attempt to highlight the undeniable attributes shared between Europe and Turkey. Turkey has gone to incredible lengths to present itself as a modern Western state, but it has in recent years begun to shed its strict secularism, allowing political parties to openly express Islamic values. These Islamic values are not presented as an opposition to the secular nature of the state. The ruling party in Turkey, while having Islamic ties, is not 'fundamentalist' but more like Christian Democrat parties in Europe.

The very fact that Caha acknowledges the Islamic character of Turkey is a new development among Turkish elites. He does not openly express himself as an Islamist or openly endorse Muslim politics, but he is not critical of them either. This attitude of accepting Islam in the political sphere reveals the softening of the traditional hard line secularism of Turkish elites. Europeans are sceptical of the Muslim nature of Turkey and this resurgence, but Caha tries to present this difference as an asset to the EU. Already in possession of vast Muslim minorities in many member states, Caha believes that allowing Turkey membership will help create a dialogue with these Muslim minorities. ${ }^{16}$ Caha asserts membership for Turkey in the EU will also help dispel the view of Europe as 'Christian only,' giving the EU enhanced international prestige. ${ }^{17}$ The argument put forth by Caha attempts to diffuse the negative image of Islam by giving it qualities that will enhance the EU, not detract. Any problems that Turkey faces are political or economic in nature. Economic issues are resolvable by policies or programs, as opposed to the difficult solution of changing culture to conform with the vague standards of being 'European.'

Many Europeans against Turkish membership to the EU do speak of the political and economic issues facing Turkey, but these often end in generalizations based on stereotypes of Muslim culture. An excellent example of this can be found in the work of Hans Arnold, a former German ambassador to the UN and current professor of Political Science in Munich. An essay he wrote for a

\footnotetext{
13 Ibid.

14 Omer Caha, "The Cultural and Religious Dimensions of the Turkish-EU Relationship," in European and Turkish Voices in Favour and Against Turkish Accession to the European Union, eds. Christiane Timmerman, Dirk Rochtus, and Sara Mels. (Brussels: P.I.E. Peter Lang, 2008,) 85.

15 Caha, 88.

16 Ibid., 97.

17 Ibid.
} 
2006 conference debating whether Turkey should be included in the EU is evidence of the inherent bias held by many Europeans against Turkey, a bias based on perceived incompatible cultural differences. Arnold sees Turkey's inclusion into European politics as merely a deterrent against Soviet influence. He plainly states they were included mainly to prevent nuclear holocaust. ${ }^{18}$ Arnold asks for a look at 'hard facts' in favour of emotional arguments, as there is "no doubt" Turkey is not European and that their inclusion in the EU would be the "suicide of Europe." ${ }^{\prime \prime}$ He blames the United States influence for Turkey being considered for membership, states Europe has geographic borders that end at the Balkans, and makes claims that most Europeans want the EU to become a new identity for the continent. ${ }^{20}$ He lambasts ethnic issues in Turkey, obscuring the fact that a major ethnic conflict was fought in Europe during the 1990s. He goes on to claim Europe is centuries ahead of Turkey due to their separation of church and state, asserting that public opinion opposing Turkish membership is racist but probably correct, and that if Turkey is allowed in then Australia and New Zealand will be next. ${ }^{21}$ Arnold provides no actual evidence for his claims despite his cry to include only 'hard facts' in the discussion of Turkey.

These are the views of an important former diplomat and professional intellectual. That Arnold espouses them not only shows ignorance, but the importance of constructed identities in both Turkey and Europe. Such a venomous attitude reflects the need felt by certain European individuals involved in the EU to keep a perceived alien Turkish culture out of the EU, thereby cultivating a formalized European identity. This is not at all a continental-wide agreement as countries such as the United Kingdom and Italy still support Turkey's bid to the EU. Still, it is easy to see that to some people in Europe, Turkey will never be able to achieve an identity deemed 'European' enough to successfully integrate. That there are millions of Muslim immigrants inside these states can be a reflection of the xenophobia felt towards Islam at the moment. Such claims by Arnold are incredibly easy to diffuse, and many are simply questionable and obviously based on personal feelings than 'hard facts.'

The notion that Europe ends at Greece has been rejected by the EU already as Cyprus and Malta are members. Instead of seeing Turkey as only a forced partner against the Soviets, Arnold could see Turkey as a fellow loyal NATO ally committed to helping the West for over fifty years. It is heavily debated that Europeans want the EU to be more than an economic union, and the assertion that Turkey does not have a secular nature and rejects Enlightenment values ignores the entire history of the state of Turkey. Asserting that Turkey's entrance will allow all sorts of non-European countries to be absorbed is preposterous, and it is doubtful that if France still held Algeria it would not be considered European, with Istanbul and Greece following similar logic.

The view that Turkey is somehow alien is one which imparts a strange threatening quality over the country, even when the author is in favour of Turkish membership to the EU. While Arnold saw Turkey as a threat to some nonexistent culture spanning Europe, Ingmar Karlsson cannot help but see threatening elements surrounding Turkey. Karlsson believes Turkey should be allowed in according to the criteria set up by the EU, as it was not until ascension really began to become

\footnotetext{
${ }^{18}$ Hans Arnold, "Political Arguments Against the Accession of Turkey to the European Union," in European and Turkish Voices in Favour and Against Turkish Accession to the European Union, eds. Christiane Timmerman, Dirk Rochtus, and Sara Mels. (Brussels: P.I.E. Peter Lang, 2008,) 109

${ }^{19}$ Ibid., 112

${ }^{20}$ Ibid., 114, 116, 118.

${ }^{21}$ Ibid., 119, 123, 125.
} 
realistic that suddenly Turkey was not European enough. ${ }^{22}$ That Turkey wants to be in the West and has been working closely with the West for over seventy years shows that it is committed to Western beliefs. Despite this, Karlsson believes that if Turkey is not given EU membership, it will then revert to "fundamentalism." ${ }^{23}$ Believing that Turkey needs Western validation to prevent itself from spiralling into an autocratic, fundamentalist state is not really much different from Orientalist concepts of the nineteenth century; it would seem Turkey has been reduced to a "European burden."

Turkey has indeed looked to the West for ideas, much as any other nation state currently existing. However, Turkish reforms and rapid Westernization cannot simply be placed at Europe's feet. Turkey had to fight a war for its mere survival against Europeans. Western-style programs were set up by a Turk completely independent of outside interference. Turkey has undeniably benefited from EU ascension talks in recent years which have allowed Islamic parties like the Justice and Workers Party, or AKP, to come to power in Turkey through reforms based on meeting EU regulations. ${ }^{24}$ These again are reforms driven by Turks; the EU does not aggressively wish for these reforms to happen in Turkey. Such reforms are enabled by an existing system modeled on European politics which inherently allow for the opening up of government. Turkey is not actually adopting Western values, as they have had these beliefs at the core of governance since 1923. It is instead a strengthening of existing bonds, which allow European and even internal Turkish criticism.

Many in the EU place pride in their secular beliefs, something which Turkish society has been built to emulate. As Islam has gained more ground among political parties in Turkey and caused a certain amount of consternation among some Europeans, these same Europeans might be surprised to discover that many in Turkey are wary of Islamic politics as well. Up to the 1980s Islam was forced to the sidelines in the politics of Turkey. This would begin to change after Turkish society gradually began to open up in the aftermath of the 1980 military coup. Turkish officials were still wary into the nineties, as a 1993 article by Binnaz Toprak illustrates. A Turkish intellectual, Toprak notes that Islam was never rejected wholesale by the Turkish populace; it was just the government that kept a strident secular policy as part of its modernization programs. ${ }^{25}$ Secular politics in Turkey then have a profound influence on the type of Islamism that develops, with Islamism in Turkey accepting secular government and only wanting to free Islam from state control. ${ }^{26}$ Islamism in Turkey is a byproduct of modernization, as it has ingested Western ideas like secular government and reinterpreted these modern ideas through the lens of Islam.

Turkey's unique brand of Islam is explained as heavily based upon modern values, but to Toprak, Islam still presents a threat to society at large. Along with the increased visibility of Islam there have emerged a new class of intelligentsia influenced by Islamic ideals. These Islamic intellectuals reject overtly Western notions and ideas, such as linear progressive history and rampant capitalistic consumption. $^{27}$ Toprak then goes further and presents these Islamic scholars as anti-technology and

\footnotetext{
22 Ingmar Karlsson, “Turkey's Historical, Cultural and Religious Hertiage. An Asset to the European Union,” in European and Turkish Voices in Favour and Against Turkish Accession to the European Union, eds. Christiane Timmerman, Dirk Rochtus, and Sara Mels. (Brussels: P.I.E. Peter Lang, 2008,) 99.

23 Ibid., 103.

${ }^{24}$ Ibid., 104.

${ }^{25}$ Binnaz Toprak, "Islamist Intellectuals: Revolt against Industry and Technology," in Turkey and The West: Changing Political and Cultural Identities, eds. Metin Heper, Ayse Oncu, and Heinz Kramer. (London \& New York: I.B. Tauris \& Co Ltd, 1993,) 240.

26 Ibid.

27 Ibid., 248.
} 
science, rejecting these concepts as imperialistic. ${ }^{28}$ Supporters of Islamism are then painted as resistant to EU integration, as it would result in the final colonial goal of total assimilation. ${ }^{29}$ The Islamic intellectuals here would seem to be the most radical examples, and it is not hard to see how the Islamic movement in Turkey is painted with all the characteristics in opposition to 'modern' Turkish values. Toprak has focused on the most radical of Muslim intellectuals in order to emphasize the intense changes they will bring to society if they were allowed to gain control. There is little doubt that some would indeed act upon these beliefs, but it is hard to imagine that many Turkish citizens would completely reject technology or science to the extent of the extremists.

There are also contradictions to be found in the article itself: Toprak points out the secular nature of most Islamists, noting that many were educated in religious schools accompanied by equal amounts of secular knowledge. ${ }^{30}$ By focusing on the most outlandish Muslim academics he displays the old elite mentality, which sees Islam as a threat to the state. In reality, this movement towards Islam reflects changes in people's attitudes towards modernization. The populace has internalized these modernist ideas and now interpret them in their own way, resulting in a local mix of the West and Islam. The reference to anti-European feelings would also cause a lot of apprehension among elites in Turkey, as they have been building towards the West for decades and share many of the attitudes of the West in regards to Islam; religion has no place in governance of the modern state.

The perspective of Islam as having no place in state politics began to erode in the 1990s. Islam gained ground politically, but it was not radical in nature. Islamism in Turkey came to represent an alternative to the existing rigidly secular government, emerging as a new popular voice in politics. Haldun Gulap, writing only three years after Toprak, posits a completely different outlook on Islamism. Even though Turkey placed heavy emphasis on its Western and secular nature, in actuality it was another Third Worldist welfare state. ${ }^{31}$ Like similar regimes, it faced massive economic pressures in the 1980s and was forced to open up to allow more private enterprise, resulting in the weakening of the central state's ability to control the population. ${ }^{32}$ As society stopped providing many of the benefits for the people it once had, discontent rose and strictly Western modern ideas began to be challenged by the people. This situation allowed for Islamism to emerge as it offered an alternative to the increasingly alienating nature of the West. ${ }^{33}$ Islamism in Turkey is not a return to an old way of Muslim life, but a modern ideology that has arose specifically in reaction to current events.

Comparing Gulap and Toprak, it becomes obvious that there are competing interpretations of political Islam in Turkey. Toprak falls into the old Kemalist views of Islamic politics as he sees Islam as a fundamentalist movement whose end goal is the establishment of a new political system in total opposition to "modern" values. Gulap applies a more nuanced approach, noting the modern influences on the origin of Islamism. Where Toprak sees Islam as a threat to politics which would retard the modern development of the last century, Gulap sees Islamism as an outgrowth of modern ideas. Islamism is not traditional and it is not reasonable to compare Turkish Islamic parties to foreign ones. Political Islamic movements are products of their surroundings and this is no different in Turkey. Toprak chose to focus on the apparent anti-technology aspects of Islamic groups,

\footnotetext{
28 Toprak 251.

${ }^{29}$ Ibid., 256.

${ }^{30}$ Ibid., 245.

${ }^{31}$ Haldun Gulap, "Modernization Policies and Islamist Politics in Turkey," in Rethinking Modernity and Nationalist Identity in Turkey, eds. Sibel Bozgodan and Resat Kasaba. (Seattle \& London: University of Washington Press, 1997, ,) 54.

32 Ibid., 56.

33 Ibid., 57.
} 
positing that Islamists want to return to the past. While there are more extreme Islamists that do have these anti-technology beliefs, they are not the core of the Islamic movement. In Gulap's essay it is clear that any anti-technology or anti-science ideas in Turkish Islam focus on the blind copying of Western forms of technology and science. Islamists do not wish to return to the past but instead urge a rethinking of the unquestioned following of the West, with Muslim politicians instead pointing out the very real problems that modernity has caused for the West. Islamism in Turkey then is trying to realign the state from undiscerning interpretation of the West into a local and original interpretation of modern ideas.

As the Islamic supported AKP has formed Turkey's government since 2002, there has been a shift to consolidate this resurgence in Muslim identity with the modern values of Turkey. Anwar Alam is one scholar who attempts to link this resurgence in Islamic politics with traditional Turkish concepts of a modern state. Alam presents Islam as always present in Turkish politics, precisely because the state exerted control over it. ${ }^{34}$ As the state was seeking to replicate the West, it needed to contain Islam in the private sphere. With the 1980 coup directed at the left, the traditional opposition to the government was crushed, resulting in a power vacuum that Islam was able to step into and fill. ${ }^{35}$ The Refah party emerged as the coalition of Islamic groups, but their radical views caused the splintering off of the more mainstream AKP in the late 1990s. ${ }^{36}$ To Alam, the AKP then is synonymous with Christian Democratic Parties in Europe, as they both look to religion on ethical and cultural grounds but still position themselves within a modern 'progressive' framework. ${ }^{37}$

Alam then presents the AKP as nothing out of the ordinary--a modern political party that has its roots in issues similar to existing mainstream European political parties. The AKP is the logical continuation of modernity, a political group that continues the legacy of Western programs instilled by Kemalism. ${ }^{38}$ Alam's main difference from the earlier authors is his inclusion of Islam in the normal political spectrum, viewing the AKP as just another party playing the political game and not a radical group seeking to usurp the established order. Islamic politics are presented as more open and modern then the previous regimes; the AKP opened up politics as never before and its Islamic identity is presented as more welcoming to minorities like the Kurds. Turkey has now embraced its Muslim identity but not in a way that threatens it relationship with Europe and the West, instead basing this identity on Western beliefs of how government should be run.

Turkey has taken a turn away from the rigid secularism of the past but has not become a hard line Islamic fundamentalist state. This has not stopped many in the West from decrying developments in Turkey as a radical embrace of an anti-Western identity. Michael Rubin, a decorated Middle Eastern historian, published an article entitled "Turkey, from Ally to Enemy." He insinuates that Turkey has been co-opted by "green money" from the Arab Gulf States, criticising the increased Turkish trade in the Gulf. $^{39} \mathrm{He}$ claims that the Turkish military has failed in its duty to prevent this "fundamentalist" take over, apparently supporting non -democratic military coups. ${ }^{40} \mathrm{He}$ labels

\footnotetext{
34 Anwar Alam, "Islam \& Post-Modernism: Locating the Rise of Islamism in Turkey," in Journal of Islamic Studies, (Vol. 20, Issue 3, 2009) 357.

35 Ibid., 366.

36 Ibid., 369.

37 Alam 369.

${ }^{38}$ For an in depth overview of Kemalism and its continuing effects on Turkey, an excellent recent source is Kerem Oktem's Turkey's Engagement With Modernity: Conflict and Change In the Twentieth Century (2010).

${ }^{39}$ Michael Rubin, "Turkey from Ally to Enemy - The Disastrous Transformation of the Only Successful Muslim Country in The Middle East," in Commentary (Jul/Aug 2010, Vol. 130, Issue 1,) 82.

${ }^{40}$ Rubin, 85.
}

\section{Constellations}

Volume 2, No. 2 (Winter 2011) 
Turkey as an enemy, calling for their removal from NATO; any military support for Turkey will end up in the hands of terrorists, as Turkey is now a "problem" on the world stage. ${ }^{41}$

To Rubin, Turkey is an enemy predominantly because it has challenged Israel at times on the world stage. His rapid, outrageous and unsubstantiated claims are bizarre coming from someone supposedly so well versed in the Middle East. He claims Turkey has fallen into some sort of undemocratic government and laments the lack of a coup to remove a democratically elected government from power. Any defence of Islamism in Turkey Rubin labels as politically correct, and anyone, whether a diplomat or an academic, who continues to support Turkey has a vendetta against some outside force blinding them to the 'truth' in Turkey. Rubin seems to be most outraged that Turkey is now moving along a path that is not strictly Western in outlook. Recent years of EU stalling has pushed the AKP government (which, it should be noted, enforced the most radical political and economic changes to comply with EU expectations) to orient itself increasingly to countries in the East. That Turkey would dare open a dialogue with its immediate neighbours causes Rubin to label Turkey an enemy to the West. With growing consternation over Turkish European identity, and little headway towards EU membership, one cannot expect Turkey to simply wait for the West forever.

In recent decades Turkey has undergone a political identity shift. Once an unquestionably staunch secular state with its orientation exclusively pointed towards the West, Turkey has seen a shift towards a more openly hybrid political identity. This re-conception of Turkey has not caused a radical shift towards fundamentalism, but has simply involved the end of blindly accepting Western notions of progress and modernity. Turkey still hopes to be included in the EU and continues to campaign for membership. The process of EU ascension has brought changes for the better to Turkey, allowing government to operate more freely. The opening of Turkish government has ironically allowed an Islamic party to come to power, causing anxiety among the West as any Islamic politics seem to reinforce the perceived non-European identity of Turkey. The Islamic identity of Turkey is under siege from within and without, as both Turks and Westerners view Islamic political parties with a great deal of suspicion.

A closer look at the politics in Turkey reveals that these political parties are not attempting to turn back the clock, but genuinely depend on modern ideas for their existence. Turkey's politicians have simply begun to accept the nation's Islamic heritage, a heritage that has always been there. Turkey is in possession of a political culture incredibly entrenched in Western values and structures, but that does not mean it is completely European either. Much like any modern European state, influences from abroad and at home coalesce to form an identity that is unique but not antagonistic to European values. For many who stand in opposition to Turkey, the arguments they present focus on so called 'realities' supposedly backed by history, but are simply acts of constructed othering. By creating a specific division between Turkey and Europe, those opposing Turkey solely because of their 'alien' culture are little different than nineteenth century Orientalists. The reality is that Turkey is mostly centered in Asia and is a Muslim country; however, Turkey is also a European state and openly directs itself towards the West. It has been a part of Europe for six hundred years and its culture is a mash up of various regions. The Turkey we know today is entrenched in the West, something its unique brand of Islamic politics can attest to.

${ }^{41}$ Ibid., 86. 


\section{Bibliography}

Alam, Anwar. "Islam \& Post-Modernism: Locating the Rise of Islamism in Turkey." Journal of Islamic Studies 20, 3. 2009. 352-375.

Arnold, Hans. "Political Arguments Against the Accession of Turkey to the European Union" In European and Turkish Voices in Favour and Against Turkish Accession to the European Union. Eds. Christiane Timmerman, Dirk Rochtus, and Sara Mels. Brussels: P.I.E. Peter Lang. 2008. 109-126.

Caha, Omer. "The Cultural and Religious Dimensions of the Turkish-EU Relationship." In European and Turkish Voices in Favour and Against Turkish Accession to the European Union. Eds. Christiane Timmerman, Dirk Rochtus, and Sara Mels. Brussels: P.I.E. Peter Lang. 2008. 85-98.

Gulap, Haldun. "Modernization Policies and Islamist Politics in Turkey." In Retbinking Modernity and Nationalist Identity in Turkey. Eds. Sibel Bozgodan and Resat Kasaba. Seattle \& London: University of Washington Press. 1997. 52-63.

Karlsson, Ingmar. "Turkey's Historical, Cultural and Religious Hertiage. An Asset to the European Union." In European and Turkish Voices in Favour and Against Turkish Accession to the European Union. Eds. Christiane Timmerman, Dirk Rochtus, and Sara Mels. Brussels: P.I.E. Peter Lang. 2008. 99-108.

Lundgren, Asa. “The Case of Turkey: Are Some Candidates More 'European’ than Others?” In Questioning EU Enlargement: Europe in Search of Identity. Ed. Helen Sjursen. London \& New York: Routledge. 2006. 121-141.

Rubin, Michael. "Turkey from Ally to Enemy-The Disastrous Transformation of the Only Successful Muslim Country in The Middle East." Commentary 130, 1. 2010. 81-86.

Said, Edward. “Orientalism 25 Years Later: Worldly Humanism vs. The Empire Builders.” Accessed April 8, 2011, http://www.counterpunch.org/said08052003.html.

Spiering, Menno. "Euro-sceptic Concerns about National Identity in the European Union and Turkey." In Turkey and the European Union: Prospects for a Difficult Encounter. Eds. Esra Lagro and Knud Erik Jorgensen. New York: Palgrave Macmillan. 2007. 169-185.

Tacar, Pulat. "Socio-cultural Dimensions of Accession Negotiations" In Turkey and the European Union: Prospects for a Difficult Encounter. Eds. Esra Lagro and Knud Erik Jorgensen. New York: Palgrave Macmillan. 2007. 125-146.

Toprak, Binnaz. "Islamist Intellectuals: Revolt against Industry and Technology." In Turkey and the West: Changing Political and Cultural Identities. Eds. Metin Heper, Ayse Oncu, and Heinz Kramer. London \& New York: I.B. Tauris \& Co Ltd. 1993. 237-257. 